\title{
Evaluation of Some Secondary Metabolites and Determination of the Antioxidant Potential of Different Extracts from the Plant of Pteridium aquilinum
}

\author{
Arnaud W. G. Tamba Sompila1,2,3*, Aimé B. Madiélé Mabika1,4, Nadia P. G. Pambou-Tobi1,2,3, \\ Tsiba Gouollaly ${ }^{4,5}$, Jacques E. Moussounga ${ }^{1,2,3}$, Gloria L. L. Bissombolo N'simba ${ }^{3}$, \\ Roniche Nguie ${ }^{1,6}$, Louis Matos ${ }^{3}$

\footnotetext{
${ }^{1}$ National Institute for Research in Engineering Sciences, Innovation and Technology, Scientific City, Brazzaville, Congo ${ }^{2}$ Laboratory of Food and Medical Bioprocesses, National Polytechnic School, Marien Ngouabi University, Brazzaville, Congo ${ }^{3}$ National Polytechnic School, Marien Ngouabi University, Brazzaville, Congo

${ }^{4}$ Plant and Life Chemistry Unit, Faculty of Science and Technology, Marien Ngouabi University, Brazzaville, Congo

${ }^{5}$ National Institute for Research in Health Sciences, Scientific City, Brazzaville, Congo

${ }^{6}$ Pole of Excellence in Food and Nutrition, Faculty of Science and Technology, Marien Ngouabi University, Brazzaville, Congo Email: *arnaud.wens@gmail.com
}

How to cite this paper: Sompila, A.W.G.T., Mabika, A.B.M., Pambou-Tobi, N.P.G., Gouollaly, T., Moussounga, J.E., N'simba, G.L.L.B., Nguie, R. and Matos, L. (2021) Evaluation of Some Secondary Metabolites and Determination of the Antioxidant Potential of Different Extracts from the Plant of Pteridium aquilinum. American Journal of Analytical Chemistry, 12, 506-519. https://doi.org/10.4236/ajac.2021.1212032

Received: November 19, 2021 Accepted: December 27, 2021 Published: December 30, 2021

Copyright $\odot 2021$ by author(s) and Scientific Research Publishing Inc. This work is licensed under the Creative Commons Attribution International License (CC BY 4.0).

http://creativecommons.org/licenses/by/4.0/ (c) (i) Open Access

\begin{abstract}
The present study aims to make an evaluation of some secondary metabolites and determination of the antioxidant potential of $P$. aquilinum plant extracts obtained by means of a simple and rapid TLC method. The latter revealed the presence of terpenes, sterols, steroids, flavonoids, polyphenols, saponins, sugars and amino acids. The evaluation of the potential antioxidant was assessed on phenolic and flavonoid compounds. These compounds' dosages revealed different levels, but the highest antioxidant activity was found in the hydro-ethanol extract followed by the aqueous extract. Among the two families of evaluated antioxidants, phenolic compounds were found to be higher in the hydroethanolic extract $\left(75.18 \mathrm{mgEAG} / \mathrm{gM}_{\mathrm{S}}\right.$ ), followed by the aqueous extract (66.78 $\left.\mathrm{mgEAG} / \mathrm{gM}_{\mathrm{s}}\right)$ and lower in the ethanolic extract $\left(12.39 \mathrm{mgEAG} / \mathrm{gM}_{\mathrm{s}}\right)$. Whereas flavonoids, less significantly elevated, showed values of $2.58 \mathrm{mgECa} / \mathrm{gM}_{\mathrm{S}}$ for the hydro-ethanolic extract, $2.24 \mathrm{mgECa} / \mathrm{gM}_{\mathrm{S}}$ for the aqueous extract and 1.58 $\mathrm{mgECa} / \mathrm{gM}_{\mathrm{S}}$ for the ethanolic extract. However, the antiradical activity was also evaluated. Contrary to the antioxidant activity, the most important antiradical activity was observed on the hydroethanolic extract with a rate of $3.61 \mathrm{mg} / \mathrm{mL}$, then a weak activity on the aqueous and ethanolic extracts respectively $6.18 \mathrm{mg} / \mathrm{mL}$ and $15.81 \mathrm{mg} / \mathrm{mL}$, then less important on the aqueous
\end{abstract}


and hydro-ethanolic extracts respectively at levels of $6.18 \mathrm{mg} / \mathrm{mL}$ and 3.61 $\mathrm{mg} / \mathrm{mL}$.

\section{Keywords}

Evaluation, Extracts, Secondary Metabolites, Potential Antioxidant, Pteridium aquilinum

\section{Introduction}

Higher plants have the ability to synthesize, through complex metabolic pathways, also called secondary metabolites. These compounds are used by plants for various functions especially in response to biotic and abiotic stresses they may undergo [1]. These metabolites are listed in one of three classes: polyphenols, alkaloids and terpenoids. Many studies have revealed the bioactivity of these molecules in antitumor, antiviral, antimicrobial, antioxidant, anti-inflammatory activities, etc. Plants containing these metabolites can be used in therapeutic, pharmaceutical, cosmetological and food fields [1] [2].

Antioxidants, which are secondary metabolites, appear to be nowadays the keys to longevity and our allies in the fight against modern diseases. They are protective elements that have an extreme variety of structures and biological activities and act as free radical scavengers. Therefore, an antioxidant is defined as a substance capable of preventing or slowing down the oxidation of other molecules [3].

Free radicals are produced daily in large quantities by the organism via oxygen, which is essential to our life, and they are very reactive compounds containing a single electron and are necessary for vital mechanisms [4]. But they become harmful when they are in excess and induce some damage to the structure of proteins, lipids [5], nucleic acids [6] by causing oxidative stress that contributes to the process of accelerated cellular aging and the development of many human diseases such as cardiovascular disease, cancer, arteriosclerosis [6], diabetes, Alzheimer's disease, rheumatism [7] [8].

According to [9], in order to avoid the serious consequences of oxidative stress, it is necessary to maintain the balance between oxidants and antioxidants, in order to preserve the optimal physiological performance of the organism. The adequate consumption of antioxidants is essential. Considered as defense systems, they can be endogenous or exogenous, of nutritional origin.

Endogenous antioxidants are produced by our body. These include enzymatic systems such as superoxide dismutases, catalases, glutathione peroxidases and thioredoxin systems, which are known to be very effective in detoxifying ROS (reactive oxygen species). The main non-enzymatic antioxidants present in the human body are glutathione, bilirubin, sex hormones, uric acid, coenzyme $\mathrm{Q}$, melanin, $\alpha$-tocopherol and lipoic acid [10]. They are permanently present in our body but their quantity decreases with age [11]. 
In nature, and particularly in the plant world, plants contain many bioactive substances that have antioxidant properties. For this reason, it is very interesting to search and identify natural antioxidants from plants [12] [13]. Moreover, according to [9], numerous epidemiological and clinical studies confirm the undeniable role of regular consumption of fruits and vegetables in reducing the risk of cancers and chronic diseases, especially cardiovascular diseases.

For a very long time, medicinal plants were the main recourse for human beings for the manufacture of pharmaceutical remedies [14]. An attitude that may also be related to the ancestral culture and civilization, which is based entirely or partially on herbal medicine because of the effectiveness, accessibility and availability of medicinal plants [15].

The aim of the present study is to evaluate the antioxidant activity of the species Pteridium aquilinum L. Kuhn. Thus, this plant's analysis was based on the partial scanning of secondary metabolites followed by the determination of total polyphenols and flavonoids of three different extracts (aqueous, hydro-ethanolic and ethanolic) in vitro using different methods.

\section{Materials and Methods}

\subsection{Plant Material}

The fern plant was purchased in the local market (the tsieme) in one of the northwestern districts of Brazzaville. The part used in this study is made up of fronds (Figure 1) maintained in the shelter of the light and at room temperature $\left(25^{\circ} \mathrm{C}\right)$ during approximately five (05) days. The dry matter was then crushed with an apparatus of type IKA-WERKE Gmbh-CO-KG, D-79219 Staufen, equipped with a sieve of granulometry $0.25 \mathrm{~mm}$.

\subsection{Methods}

\subsubsection{Preparation of Extracts}

The chemical screening of $P$. aquilinum on thin layer was performed on the ethanolic extract.

Concerning the determination of total polyphenols and flavonoids, the different extracts were obtained by mixing $40 \mathrm{~g}$ of the plant material in $2 \times 200 \mathrm{~mL}$ of different organic solvents for the preparation of aqueous, hydro-ethanolic in

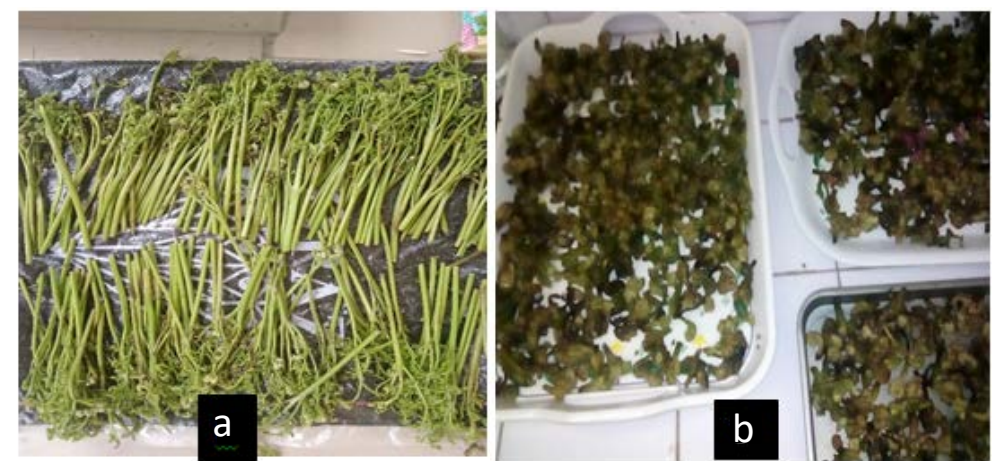

Figure 1. (a) Rhizomes of fern ( $P$. aquilinum); (b) Fronds of $P$. aquilinum. 
the proportions $50 \%(\mathrm{v} / \mathrm{v})$ and ethanolic in the proportions $50 \%(\mathrm{v} / \mathrm{v})$ respectively. The mixture was macerated under stirring for $48 \mathrm{~h}$ and then filtered through a Wattman filter paper. The filtrate obtained was concentrated to dryness at $50^{\circ} \mathrm{C}$ under reduced pressure using a rotary evaporator model N-1 (Eyela, Tokyo Rikakikal, Co., Ltd., Japan). This filtrate was placed in an oven at $25^{\circ} \mathrm{C}$ for $24 \mathrm{~h}$ and then stored in a cool place $\left(+4^{\circ} \mathrm{C}\right)$ waiting to be analyzed. The alcohol used is Cooper brand preparatory at $90 \%$ vol.

\subsubsection{Preparation of Assay Solutions at Different Dilutions}

A series of glass tubes were used to prepare the solutions of different extracts with the corresponding solvents. $40 \mathrm{mg}$ of ethanolic extract, $80 \mathrm{mg}$ of hydroethanolic extract and $160 \mathrm{mg}$ of aqueous extract respectively were measured to prepare the assay solutions by adding $2 \mathrm{~mL}$ of solvent (Ethanol, Water-Ethanol and Water) in each of the tubes. Everything was mixed under magnetic stirring for a few moments and the stock solutions for each extract were obtained.

From the stock solutions, we also prepared the subsequent solutions for each extract by 1/10 dilution. We prepared a total of 4 (S1 to S4) of each extract from which we obtained 12 following solutions.

\section{Thin Layer Chromatography Method: TLC}

\subsection{Chemical Screening by TLC}

The different extracts were subjected to analysis by Thin Layer Chromatography (TLC), performed on silica 60 F254 plates (MercK). Different elution systems were used according to the types of families sought. After development, the plates were examined under the UV lamp at $254 \mathrm{~nm}$ and $365 \mathrm{~nm}$. The spots were then revealed by conventional detection reagents prepared according to standard methods [16].

\subsection{Thin Layer Chromatography of Antioxidant Activity}

Quantitative identification of substances with antioxidant activity was performed according to the "bioautography" method [17] by thin layer chromatography where antioxidant activity was revealed with DPPH, according to [18]. TLC was performed on silica gel chromatographic plate $60 \mathrm{~F} 254$ on $20 \mathrm{~cm} \times 20 \mathrm{~cm}$ aluminum foil support of Merck brand.

TLC was performed in normal phase on aluminum plates with the solution of ethyl acetate/formic acid/water in proportions $9 / 0.5 / 0.5$. The chromatogram obtained was revealed by spraying with the Node solution $(0.5 \mathrm{~g}$ of 2 amino diphenyl borinate $+0.5 \mathrm{~g}$ of PEG400 $+100 \mathrm{~mL}$ of ethanol).

Observation of the plates was performed in UV-visible and UV at $366 \mathrm{~nm}$, before and, in some cases, after revelation with the appropriate reagents. The UV lamp used is a CAMAG lamp with a wavelength ranging from 254 to $366 \mathrm{~nm}$.

\subsection{Polyphenol Analysis}

The total polyphenol content of the different extracts of the $P$. aquilinum plant 
was determined according to the Folin-Ciocalteu method. For this purpose, to each $0.1 \mathrm{~mL}$ of each extract (aqueous, hydro-ethanolic and alcoholic) is added, $0.9 \mathrm{~mL}$ of distilled water, followed by the addition of $0.9 \mathrm{~mL}$ of $(1 \mathrm{~N})$ Folin-Ciocalteu reagent. Immediately thereafter, $0.2 \mathrm{~mL}$ of $\mathrm{Na}_{2} \mathrm{CO}_{3}$ (20\%) was added. The resulting mixture was incubated at room temperature of $25^{\circ} \mathrm{C}$ for about 40 minutes in the dark.

The absorbance was measured with a spectrophotometer UV-Visible Spectrophotometer, model Gd-752n at $725 \mathrm{~nm}$ against a methanol solution used as blank. The results obtained were expressed as $\mathrm{mg}$ gallic acid equivalent per gram of dry matter (EGA/g Ms).

\subsection{Total Flavonoids Analysis}

The total flavonoid content of the different extracts of $P$. aquilinum was obtained using Aluminium Trichloride $\left(\mathrm{AlCl}_{3}\right)$ [19]. In a $100 \mathrm{~mL}$ flask was successively introduced $250 \mu \mathrm{L}$ of each extract (aqueous, hydroethanolic and alcoholic) $1 \mathrm{~mL}$ of distilled water, $7.5 \mu \mathrm{L}$ of $\mathrm{NaNO}_{2}(5 \%)$. The mixture was allowed to stand for 5 minutes. Then $75 \mu \mathrm{L}$ of $\mathrm{AlCl}_{3}(10 \%)$, was added before letting it stand again for $6 \mathrm{~min}$. Then $500 \mu \mathrm{L}$ of $(1 \mathrm{~N}) \mathrm{NaOH}$ and $2.5 \mathrm{~mL}$ of distilled water were added successively to the mixture. The analyses were performed at $25^{\circ} \mathrm{C}$.

The following reagents: $\mathrm{NaOH}, \mathrm{NaNO}_{2}, \mathrm{Na}_{2} \mathrm{CO}_{3}$, ethyl acetate and formic acid are all from Merck.

The absorbance was measured by UV-visible spectrophotometer UV-Visible Spectrophotometer, model Gd-752n at $510 \mathrm{~nm}$ and the results were expressed as mg catechin equivalent per gram of dry matter (ECa/g Ms).

\subsection{Evaluation of the Anti-Free Radical Activity of Different Extracts}

\subsubsection{Method Using DPPH}

The antioxidant activity of each extract was measured using DPPH radical.

The evaluation of the anti-free radical activity was performed using $5 \mathrm{~mL}$ of the solution of 1.1-diphenyl-2-picrylhydrazyl (DPPH at $10 \mathrm{mg}$ in $250 \mathrm{~mL}$ of ethanol) and $100 \mu \mathrm{L}$ of each extract diluted to concentrations ranging from 1.25 to 20 or even $40 \mathrm{mg} / \mathrm{mL}$, all mixed in EDTA glass tubes. After 30 minutes of incubation in the dark, the free radical scavenging activity was measured by spectrophotometer at $517 \mathrm{~nm}$ in the dark [20]. The percentage of inhibition was calculated by the following relation:

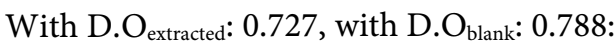

$$
\mathrm{I} \%=\frac{\mathrm{D} \cdot \mathrm{O}_{\text {blanc }}-\mathrm{D} \cdot \mathrm{O}_{\text {extrait }}}{\mathrm{D} \cdot \mathrm{O}_{\text {blanc }}} \times 100
$$

The IC50 parameter (50\% inhibitory concentration) is defined as the concentration of the substrate that causes the loss of $50 \%$ of DPPH activity. The antioxidant power is determined in such a way that an amount of the extract of a certain concentration neutralizes $50 \%$ of the DPPH radical. In order to compare 
the extracts between them, this index is obtained either by deduction from the curves of the variation of the percentage of inhibition I\% or calculated graphically by the formula of the regression of the percentages of inhibition according to different concentrations of the extracts tested with the help of the XL Stat Pro 7.5. The value of the antiradical activity, such as $y=50 \%$, corresponds to the inhibitory concentration IC50 of the studied extract [20] [21] [22].

The results expressed as IC50 were deduced from the data presented from the variation of the percentage of inhibition I\% as a function of the concentration of each extract. It should be remembered that the smaller the IC50 value, the greater the antioxidant activity of the extracts [23] [24].

The following reagents: DPPH, Folin-Colciateu, Gallic acid, Aluminum trichloride, Quercetin, Rutin, Caffeic acid and Chlorogenic acid are all from Sigma

\subsubsection{Statistical Studies}

The experiments were done in triplicate, the results were presented by the mean with its standard deviation. The analyses of variance were performed by the statistical software XL Stat Pro 7.5. The determination of significance levels was performed by the Anova test. Differences were considered significant at $\mathrm{P}<0.05$.

\section{Results and Discussion}

\subsection{Chemical Screening by TLC}

Chemical screening of $P$. aquilinum frond extracts revealed the presence of large families of chemical compounds (Figure 2). Each of the families appear as spots of different color.

The green, yellow, orange, blue, pink and purple spots observed on the chromatographic plates and in UV/visible spectroscopy, correspond to different secondary metabolics such as terpenes, sterols, steroids, flavonoids, polyphenols, saponins, sugars and amino acids.

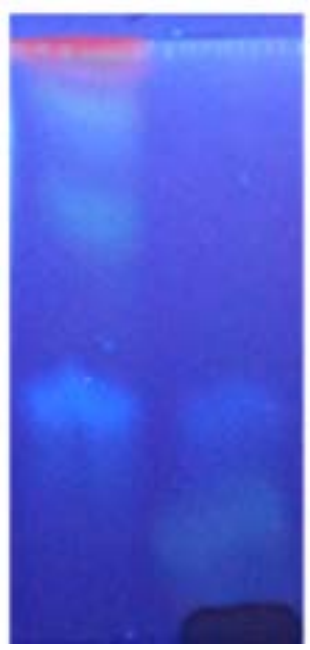

(a)

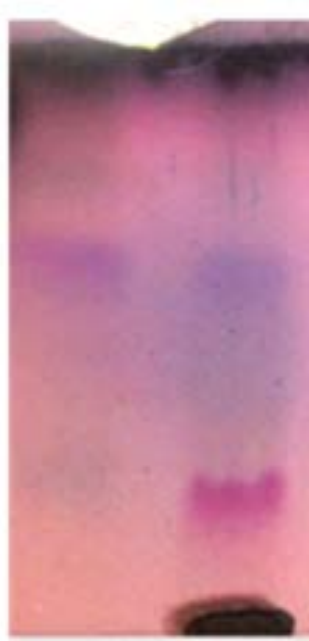

(b)

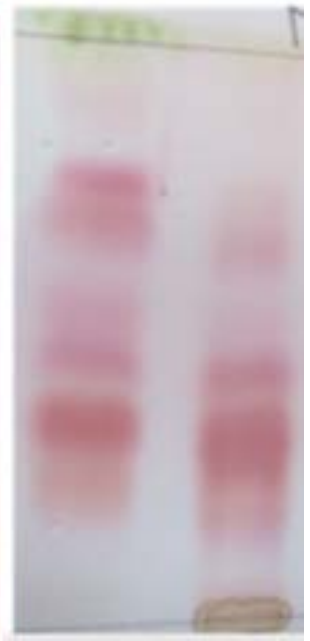

(c)

Figure 2. Research of some secondary metabolites by TLC. 
The blue, bluish-white spots observed on the chromatograms under UV/365 nm (Figure 2(a) and Figure 2(b)) revealed by the node reagent or aluminum chloride, characterizes the presence of polyphenols. Flavonoids are also revealed under UV/366 nm under various fluorescent white, pink, orange and green colors (Figures 2(a)-(c)).

Iron trichloride is the appropriate developer for tannins, the latter appear on the plate after $\mathrm{FeCl}_{3}$ development as a black or blue spot. Thymol and sulfuric vanillin reveal all glycosylated compounds [25] [26].

Some previous works have highlighted the presence of alkaloids, flavonoids, polyphenols and tannins in the fronds of $P$. aquilinum L. Kunh [27].

For this study, the focus was on the antioxidant properties of $P$. aquilinum extracts, especially the two families (polyphenols and flavonoids).

\subsection{Thin Layer Chromatography of Antioxidant Activity}

Figure 3 shows the presence of yellow-pale spots on a purple and blue background of the hydro-ethanol extract of $P$. aquilinum. This indicates that this extract, compared to the other two, contains phytocompounds likely to trap free radicals. Indeed, the chromatographic profile on TLC plate revealed at the node and observed at UV (365 nm) revealed on the one hand the blue, bluish white spots which remind the presence of polyphenols, and on the other hand, the white, pink, orange and green spots are characteristic of flavonoids.

By contrasting the chromatographic profiles of the phytochemical screening and that of the antioxidant activity assay (Figure 3), the correspondence between the active zones and the phytocompounds responsible for this activity was

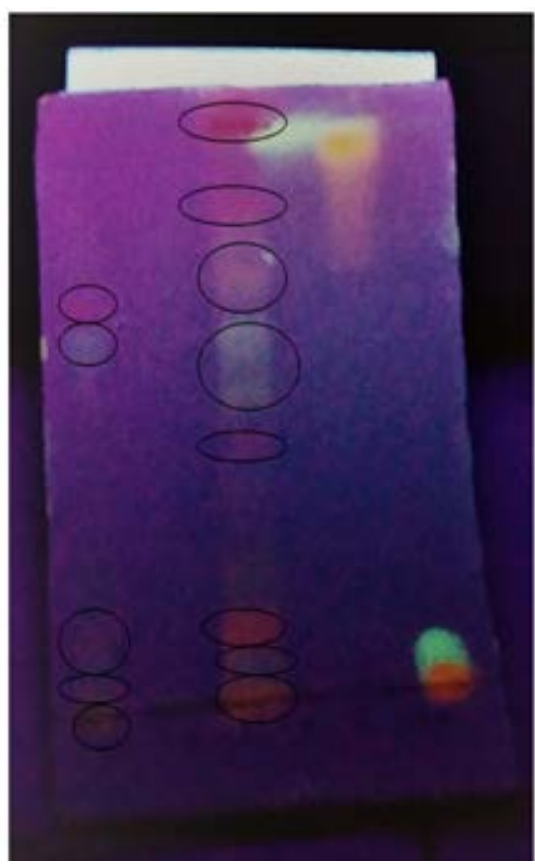

(a)

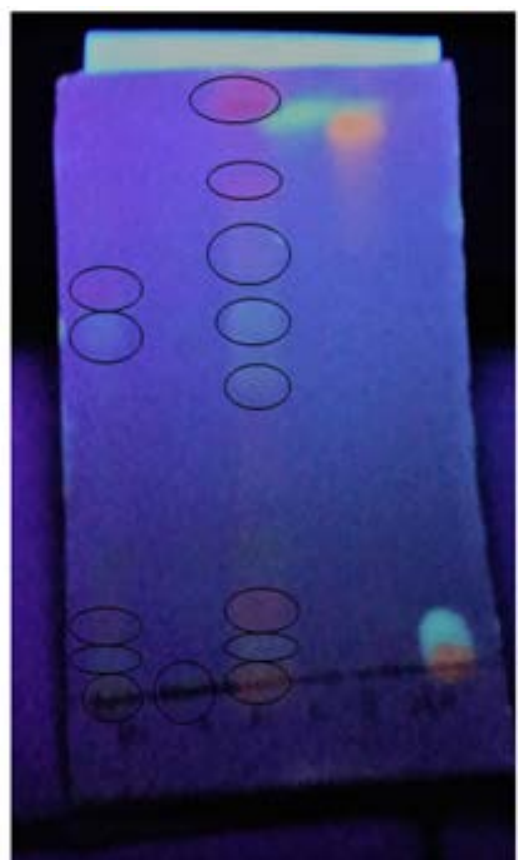

(b)

Figure 3. Chromatographic profiles of extracts and some reference compounds. 
established. In the chromatogram of the hydro-ethanolic extracts (Figure 3), the yellow spots would correspond to the antioxidant activity of flavonoids and polyphenols.

The observation of the TLC plates shows yellow, yellow-orange fluorescences corresponding to the reference compounds Quercetin (Qr) and Caffeic Acid (AcCaf). Yellow and green fluorescence which can correspond to the reference compound Chlorogenic acid (Ac.Chl). Orange fluorescence that may correspond to the reference compound Rutin (Rut) is observed. According to [28] [29], the colored fluorescences observed for the different reference compounds (Qr, Rut, Ac.Caf, Ac.Chl) are characteristic of flavonoids and polyphenols.

\subsection{Phenols and Flavonoids Content}

The determination of total phenols and flavonoids (Figure 4) in the different extracts of $\mathrm{P}$ aquilinum was done using separately the colorimetric methods (Folin-Ciolcateaux and Aluminium Trichloride).

The quantitative analysis of total polyphenols and flavonoids shows that the hydro-ethanolic and aqueous extracts are quantitatively richer than the ethanolic extract. The contents of polyphenols in the extracts are respectively $75.18 \mathrm{mg}$ $\mathrm{EAG} / \mathrm{gM}_{\mathrm{S}}$ for the hydro-ethanolic extract, $66.78 \mathrm{mgEAG} / \mathrm{gM}_{\mathrm{S}}$ for the aqueous extract and $12.39 \mathrm{mgEAG} / \mathrm{gM}_{\mathrm{S}}$ for the ethanolic extract against $2.58 \mathrm{mgECa} / \mathrm{gM}_{\mathrm{S}}$ for the flavonoids on the hydro-ethanolic extract, $2.24 \mathrm{mgECa} / \mathrm{gM}_{\mathrm{S}}$ for the aqueous extract and $1.58, \mathrm{mgECa} / \mathrm{gM}_{\mathrm{S}}$ for the ethanolic extract It can be seen that all the extracts of $P$. aquilinum are rich in polyphenols and present low levels of flavonoids.

These differences in content between the different compounds can be explained by the fact that the total polyphenols include flavonoids and other compounds.

\section{Total Polyphenols and Flavonoids}

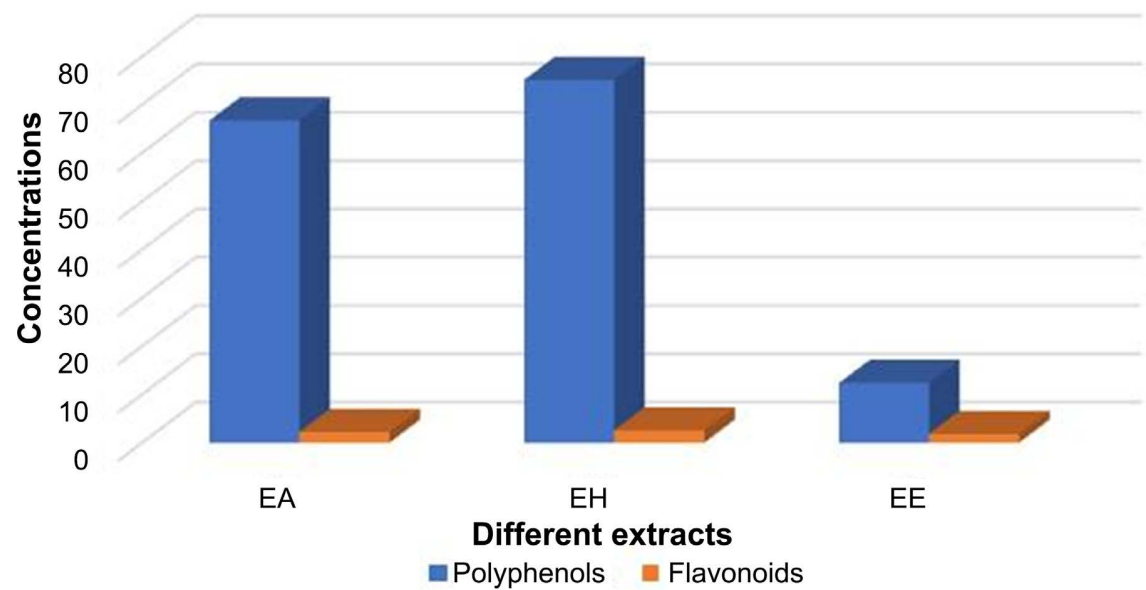

Figure 4. Dosage of total polyphenols and flavonoids in aqueous, hydro-ethanolic and ethanolic extracts. 
It is also noted that the hydroalcoholic and aqueous extracts are quantitatively richer in phenolic compounds that is, that solvents (water and water-ethanol mixture) extract better polyphenols compared to other mixtures [25] [26].

The literature reports that, it is in the alcoholic extracts that we find more phenolic compounds [30] [31] while for our case, it is in the hydroethanol and aqueous extracts that we found more phenolic compounds. The high level of these compounds in the hydroethanolic and aqueous extracts leads us to deduce that water and the water/plus alcohol mixture are solvents for better extraction of these compounds. This is due to the capacity of alcohol to inhibit the action of the polyphenol oxidase which causes the oxidation of polyphenols in plant tissues [32] for the case of solvent mixture.

It can also be noted that the stationary phase used (polyamide 6-Fluka) allowed to enrich these extracts in poly-phenolic compounds. The high contents of total polyphenols and flavonoids obtained in the present study, could be justified by the very clear evidences observed by thin layer chromatography (TLC) and the presence of these metabolites reported by several authors in the plant [33].

\subsection{Anti-Radical Activity of the Different Extracts}

\subsubsection{Percentage of DPPH Radical Inhibition}

The results of the anti-free radical activity of the different extracts on DPPH are presented in the series of Tables 1-3. Tables 1-3 show that at a low concentration of $1.25 \mathrm{mg} / \mathrm{ml}$, the hydro-ethanolic, aqueous and ethanolic extracts, present

Table 1. Anti-radical activity of the hydro-ethanolic extract of $P$. aquilinum.

\begin{tabular}{cccccc}
\hline & \multicolumn{5}{c}{ Hydroethanolic Extract } \\
\hline Concentration & $20 \mathrm{mg} / \mathrm{ml}$ & $10 \mathrm{mg} / \mathrm{ml}$ & $5 \mathrm{mg} / \mathrm{ml}$ & $2.5 \mathrm{mg} / \mathrm{ml}$ & $1.25 \mathrm{mg} / \mathrm{ml}$ \\
\hline Optical Density (O.D.) & 0.25 & 0.21 & 0.37 & 0.70 & 0.92 \\
Percentage of Inhibition (\%) & 69.76 & 60.09 & 40.46 & 24.74 & 14.51 \\
\hline
\end{tabular}

Table 2. Anti-radical activity of the aqueous extract of $P$. aquilinum.

\begin{tabular}{cccccc}
\hline & \multicolumn{5}{c}{ Aqueous Extract } \\
\hline Concentration & $20 \mathrm{mg} / \mathrm{ml}$ & $10 \mathrm{mg} / \mathrm{ml}$ & $5 \mathrm{mg} / \mathrm{ml}$ & $2.5 \mathrm{mg} / \mathrm{ml}$ & $1.25 \mathrm{mg} / \mathrm{ml}$ \\
\hline Optical Density (O.D.) & 0.33 & 0.43 & 0.64 & 0.81 & 0.92 \\
Percentage of Inhibition (\%) & 76.74 & 80.84 & 65.21 & 34.60 & 20 \\
\hline
\end{tabular}

Table 3. Anti-free radical activity on ethanolic extract of $P$. aquilinum.

\begin{tabular}{cccccc}
\hline & \multicolumn{5}{c}{ Ethanolic Extract } \\
\hline Concentration & $20 \mathrm{mg} / \mathrm{ml}$ & $10 \mathrm{mg} / \mathrm{ml}$ & $5 \mathrm{mg} / \mathrm{ml}$ & $2.5 \mathrm{mg} / \mathrm{ml}$ & $1.25 \mathrm{mg} / \mathrm{ml}$ \\
\hline Optical Density (O.D.) & 0.53 & 0.74 & 0.87 & 0.96 & 1.002 \\
Percentage of Inhibition (\%) & 50.88 & 31.63 & 18.61 & 9.95 & 6.79 \\
\hline
\end{tabular}


percentages of reduction of DPPH, respectively $14.51 \%, 20 \%$ and $6.79 \%$ but at high concentrations from $20 \mathrm{mg} / \mathrm{ml}$. We note in the same order $69.76 \%, 76.74 \%$ and $50.88 \%$. It can be seen that the values of the anti-free radical activity increase with the concentration in the extracts.

\subsubsection{0\% Inhibitory Concentrations}

The results of the anti-free radical activity were also expressed using the IC50 parameter. The IC50 is inversely related to the antioxidant capacity of a compound, so the lower the IC50 value, the higher the antioxidant activity of a compound.

The IC50 found with the ethanolic extract of $P$. aquilinum $(15.81 \mathrm{mg} / \mathrm{mL})$ is significantly higher $(\mathrm{P}<0.05)$ than that found with the aqueous extract $(6.18$ $\mathrm{mg} / \mathrm{mL})$. On the other hand, the IC50 value found with the hydroalcoholic extract $(3.61 \mathrm{mg} / \mathrm{mL})$ is significantly lower $(\mathrm{P}<0.05)$. These results are in agreement with those found by [30], where they stated that both extracts had high inhibitory power on $P$. aquilinum plant.

These low values of the inhibitory concentration 50\% (IC50) of the hydroethanolic and aqueous extracts show that they are endowed with greater antioxidant power than that of the ethanolic extract and this explains why water and the alcohol/water mixture remains the best extraction solvent for this study.

This strong inhibition of free radicals by ethanolic and aqueous extracts (Figure 5) could be justified by their high concentrations of phenolic compounds which are known to be potent compounds with free radical reducing power [34] [21].

We can also note that the anti-radical activity is the opposite of the antioxidant activity. Indeed, the polyphenolic compounds are known as powerful compounds having a reducing power of the free radicals [21].

\section{Concentration inhibitrice $\mathrm{Cl} 50$}

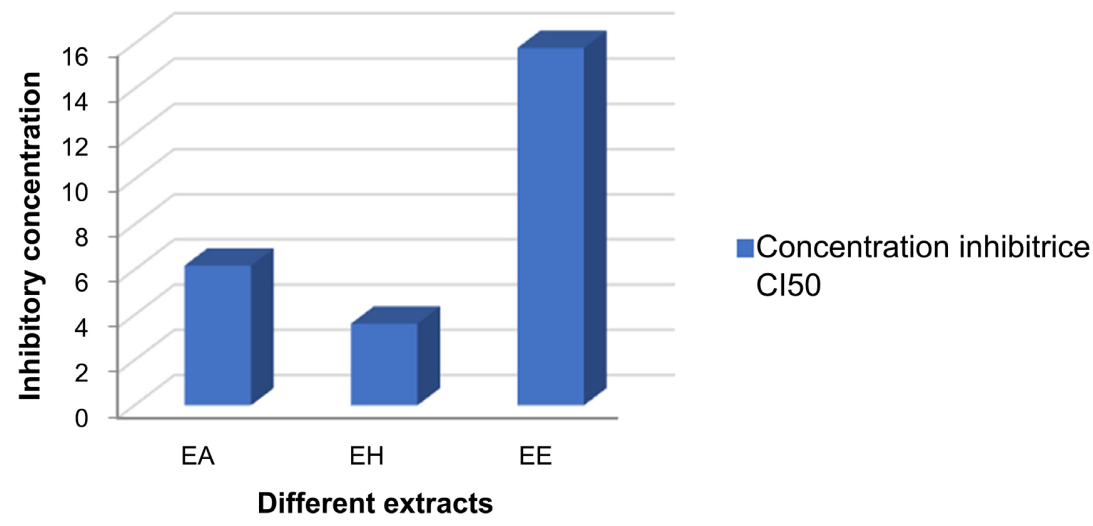

Figure 5. Evaluation of the antiradical activity in the different extracts.

\section{Conclusion}

This study showed that the hydro-ethanolic extract of the plant of $P$. aquilinum 
presented a great wealth in polyphenols and total flavonoids. It also revealed that the other aqueous and ethanolic extracts are rich in polyphenols and less in total flavonoids. In addition, the ethanolic extract is potentially rich in anti-radical compounds. The two others (aqueous and hydro-ethanolic) are less rich in antiradical compounds. These results allow encouraging the users and consumers of the plant of $P$. aquilinum, which contains polyphenols and total flavonoïdes in sufficient quantity. This plant, which is already consumed by the Brazzaville and Congolese population, must be better popularized, especially its use as a potential additive in place of synthetic compounds.

\section{Acknowledgements}

We would like to thank all the managers and colleagues of the laboratories where we carried out this work, in particular those of the National Institute of Research in Health Sciences (IRSSA).

Many thanks to Professor Jacques Emmanuel Moussounga and to Gloria Lisa Bissombolo N'Simba, our student.

\section{Conflicts of Interest}

No conflict on this article.

\section{References}

[1] Thomas, M. (2011) Nouvelles méthodologies d'extraction, de fractionnement et d'identification: Application aux molécules bioactives de l'argousier (Hippophaë rhamnoides) thèse de doctorat. Université Toulouse, Toulouse.

[2] Rispail. N., Nash, R. and Webb, K.J. (2005) Secondary Métabolite Profiling. In: Márquez, A.J., Ed., Lotus japonicas Handbook, Springer, Dordrecht, 341-348. https://doi.org/10.1007/1-4020-3735-X 33

[3] Flora, S.J.S. (2009) Structural, Chemical and Biological Aspects of Antioxidants for Strategies against Metal and Metalloid Exposure. Oxidative Medicine and Cellular Longevity, 2, Article ID: 873634. https://doi.org/10.4161/oxim.2.4.9112

[4] Bartosz, G. (2003) Generation of Reactive Oxygen Species in Biological Systems. Comments on Toxicology, 9, 5-21. https://doi.org/10.1080/08865140302420

[5] Pourrut, B. (2008) Implication du stress oxydatif dans la toxicité du plomb sur une plante modèle, Vicia faba. Thèse pour l'obtention du Diplôme de Doctorat à l'Institut National Polytechnique de l'Université de Toulouse spécialité: Ecotoxicologie, France.

[6] Favier, A. (2003) Le stress oxydant. Intérêt conceptuel et expérimental dans la compréhension des mécanismes des maladies et potentiel thérapeutique. L'actualité chimique, 11, 108-115.

[7] BenTekaya, I. and Hassouna, M. (2005) Corps gras, Lipides, Étude de la stabilité oxydative de l'huile d'olive vierge extra tunisienne au cours de son stockage. Oilseeds and Fats, Corps and Lipids, 12, 447-454. https://doi.org/10.1051/ocl.2005.0447

[8] Mezouar, D., Lahfa, F.B., Djaziri, R. and Boucherit-Otmani, Z. (2014) Évaluation de l'activité antioxydante de Berberis vulgaris L. Phytothérapie, 12, 297-301. https://doi.org/10.1007/s10298-014-0867-1

[9] Derbel, S. and Ghedira, K. (2005) Les phytonutriments et leur impact sur la santé. Phytothérapie, 3, 28-34. https://doi.org/10.1007/s10298-005-0061-6 
[10] Laguerre, M., Lecomte. J. and Villeneuve. P. (2007) Review of Evaluation of the Ability of Antioxidants to Counteract Lipid Oxidation: Existing Methods, New Trends and Challenges. Progress in Lipid Research, 46, 244-282.

https://doi.org/10.1016/j.plipres.2007.05.002

[11] Mika, A., Minibayeva, F., Beckett, R. and Lüthje, S. (2004) Possible Functions of Extracellular Peroxidases in Stress-Induced Generation and Detoxification of Active Oxygen Species. Phytochemistry Reviews, 3, 173-193. https://doi.org/10.1023/B:PHYT.0000047806.21626.49

[12] Merouane, A., Noui, A., Medjahed, H., Nedjari Benhadj Ali, K. and Saadi, A. (2014) Activité antioxydante des composés phénoliques d'huile d'olive extraite par méthode traditionnelle. International Journal of Biological and Chemical Sciences, 8, 1865-1870. https://doi.org/10.4314/ijbcs.v8i4.45

[13] Scalbert, A. and Williamson, G. (2000) Dietary Intake and Bioavailablity of Polyphenols. The Journal of Nutrition, 130, 2073S-2085S. https://doi.org/10.1093/jn/130.8.2073S

[14] Hebi, M. and Eddouks, M. (2016) Évaluation de l'activité antioxydante de Stevia rebaudiana. Phytothérapie, 14, 17-22. https://doi.org/10.1007/s10298-015-0999-y

[15] Akharalyi, F.C. and Boboye, B. (2010) Antibacterial and Phytochemical Evaluation of Three Medicinal Plants. Journal of Natural Products, 3, 27-34.

[16] Bladt, S. and Wagner, H. (1996) Plant Drug Analysis, a Thin Layer Chromatography Atlas. 2nd Edition, Springer-Verlag, Berlin. https://doi.org/10.1007/978-3-642-00574-9

[17] Gangopadhyay, M., Dewanjee, S., Bhattacharya, N., Khanra, R. and Dua, T.K. (2015) Bioautography and Its Scope in the Field of Natural Product Chemistry. Journal of Pharmaceutical Analysis, 5, 75-84. https://doi.org/10.1016/j.jpha.2014.06.002

[18] N'Guessan, K., Kadja, B., Zirihi, G., Traoré, D. and Aké-Assi, L. (2009) Screening phytochimique de quelques plantes médicinales ivoiriennes utilisées en pays Krobou (Agboville, Côte-d'Ivoire). Sciences \& Nature, 6, 1-15. https://doi.org/10.4314/scinat.v6i1.48575

[19] Mansouri, A., Embarek, G., Kokkalou, E. and Kefalas, P. (2005) Phenolic Profile and Antioxidant Activity of the Algerian Ripe Date Palm Fruit (Phoenix dactylifera). Food Chemistry, 89, 411-420. https://doi.org/10.1016/j.foodchem.2004.02.051

[20] Mensor, L.L., Menezes, F.S., Leitão, G.G., Reis, A.S., Santos, T.C., Coube, C.S. and Leitão, S.G. (2001) Screening of Brazilian Plant Extracts for Antioxidant Activity by the Use of DPPH Free Radical Method. Phytotherapy Research, 15, 127-130. https://doi.org/10.1002/ptr.687

[21] Brand-Williams, W., Cuvelier, M.E. and Berset, C. (1995) Use of a Free Radical Method to Evaluate Antioxidant Activity. Food Science and Technology, 28, 25-30. https://doi.org/10.1016/S0023-6438(95)80008-5

[22] Nouioua, W. (2012) Thème Biodiversité et Ressources phytogénétiques d'un écosystème forestier "Paeonia mascula (L.) Mill”, Mémoire présenté à la Faculté des Sciences de la nature et la vie Département de Biologie végétale et d'Écologie Pour l'obtention du diplôme de MAGISTER Option: Biodiversité et gestion des écosystèmes.

[23] Popovici, C., Saykova, I. and Tylkowski, B. (2009) Evaluation de l'activité antioxydant des composés phénoliques par la réactivité avec le radical libre DPPH. Revue de Génie Industriel, 4, 25-39.

[24] Bastos, D.H., Saldanha, L.A., Catharino, R.R., Sawaya, A., Cunha, I.B., Carvalho, P.O., et al. (2007) Phenolic Antioxidants Identified by ESI-MS from Yerba Maté (Ilex paraguariensis) and Green Tea (Camelia sinensis) Extracts. Molecules, 12, 423-432. https://doi.org/10.3390/12030423 
[25] Bekro, Y., Mamyrbekova, J., Boua, B., Bi, F.T. and Ehile, E. (2007) Étude ethnobotanique et screening phytochimique de Caesalpinia benthamiana (Baill.) Herend. et Zarucchi (Caesalpiniaceae). Sciences \& Nature, 4, 217-225. https://doi.org/10.4314/scinat.v4i2.42146

[26] Adou, L.M.D., Kone, M.W., Ipou, J.I. and N'Guessan, E.K. (2016) Ethnobotanique et analyse phytochimique qualitative de Pteridium aquilinum. (L.) Kühn (Dennstaedtiaceae), une Ptéridophyte utilisée comme plante médicinale en Côte d'Ivoire. International Journal of Biological and Chemical Sciences, 10, 1783-1792. https://doi.org/10.4314/ijbcs.v10i4.27

[27] Lukavky, K. (1996) les fougères, Rapport des associes de la biodiversité $n^{\circ} 3$ canada, $12 \mathrm{p}$.

[28] Markham, K.R. (1982) Technique of Flavonoid Identification. Academic Press, London.

[29] Rizk, A.M. (1982) Constituents of Plants Growing in Qatar. Fitoterapia, 52, 35-42.

[30] Nguie, R., Gouollaly, T., Sompila, A.W.G.T., Moussounga, J.E., Dzondo, M.G., Pambou-Tobi, N.P.G., Diakabana, P. and Gampoula, R.H. (2021) Evaluation of Potential Extracts Antioxydant (Aqueous, Hydro-Ethanolic and Ethanolic) of an Aquatic Plant from the River Djoue (Ledermanniella schlechteri). Open Journal of Applied Sciences, 11, 254-263. https://doi.org/10.4236/ojapps.2021.113018

[31] Abdille, M., Singh, R., Jayaprakasha, G. and Jena, B. (2005) Antioxidant Activity of the Extracts from Dillenia indica Fruits. Food Chemistry, 90, 891-896.

https://doi.org/10.1016/j.foodchem.2004.09.002

[32] Yao, L.H., Jiang, Y.M., Shi, J., Tomas-Barberan, F.A., Datta, N., Singanusong, R. and Chen, S.S. (2004) Flavonoids in Food and Their Health Benefits. Plant Foods for Human Nutrition, 59, 113-122. https://doi.org/10.1007/s11130-004-0049-7

[33] Muanda, F. (2010) Identification de polyphenols, évaluation de leur activité antioxydante et étude de leurs propriétés biologiques. Thèse de doctorat, Université paul verlaine-Metz, $294 \mathrm{p}$.

[34] Ndiaye, E.M., Yousra, Y.E.I., Alioune, S., Ayessou, N.C., Harhar, H., Cisse, M. and Tabyaoui, M. (2021) Secondary Metabolites and Antioxidant Activity of Different Parts of the Baobab Fruit (Adansonia digitata L.). Food and Nutrition Sciences, 12, 732-741. https://doi.org/10.4236/fns.2021.127055 


\section{Nomenclature}

EGA: Gallic Acid Equivalent;

ECa: Catechin Equivalent;

Qr: Quercetin;

Rut: Rutin;

Ac.Caf: Caffeic Acid;

Ac.Chl: Chlorogenic Acid;

$\mathrm{M}_{\mathrm{s}}$ : Dry Matter;

mg: Milligramme;

$\mathrm{mL}$ : Milliliter;

P. aquilinum: Pteridium aquilinum;

CCM: Thin Layer Chromatography;

IC50: 50\% Inhibitory Concentrations;

DPPH: 1.1-Diphenyl-2-Picrylhydrazyl;

TVF: Total Flavonoid Content;

TPP: Total PolyPhenol Content;

PEG400: Polyéthylèneglycole 400. 